Western University

Scholarship@Western

Aboriginal Policy Research Consortium International (APRCi)

2010

Exploring the relationship between aboriginal tourism and community development

John W. Colton

Kelly Whitney-Squire

Follow this and additional works at: https://ir.lib.uwo.ca/aprci

Part of the Recreation, Parks and Tourism Administration Commons

Citation of this paper:

Colton, John W. and Whitney-Squire, Kelly, "Exploring the relationship between aboriginal tourism and community development" (2010). Aboriginal Policy Research Consortium International (APRCi). 287.

https://ir.lib.uwo.ca/aprci/287 
This article was downloaded by: [University of Western Ontario]

On: 16 December 2012, At: 07:09

Publisher: Routledge

Informa Ltd Registered in England and Wales Registered Number: 1072954 Registered

office: Mortimer House, 37-41 Mortimer Street, London W1T 3J H, UK

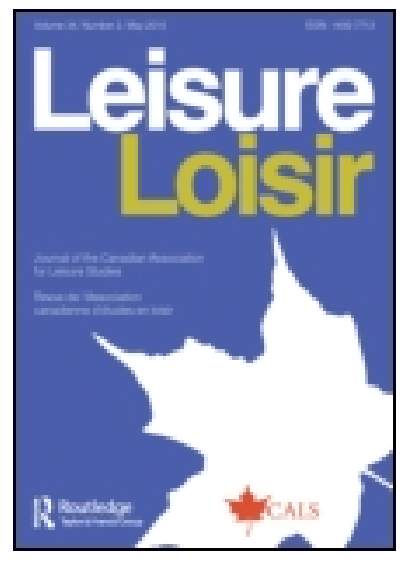

\title{
Leisure/Loisir
}

Publication details, including instructions for authors and subscription information:

http:/ / www. tandfonline.com/loi/ rloi20

\section{Exploring the relationship between aboriginal tourism and community development}

\author{
John W. Colton ${ }^{a} \&$ Kelly Whitney-Squire ${ }^{a}$ \\ a School of Recreation Management and Kinesiology, Acadia \\ University, Wolfville, Nova Scotia, Canada, B4P 2R6 \\ Version of record first published: 05 Nov 2010.
}

To cite this article: J ohn W. Colton \& Kelly Whitney-Squire (2010): Exploring the relationship between aboriginal tourism and community development, Leisure/ Loisir, 34:3, 261-278

To link to this article: http:// dx. doi.org/ 10.1080/ 14927713.2010.521321

\section{PLEASE SCROLL DOWN FOR ARTICLE}

Full terms and conditions of use: http://www.tandfonline.com/page/terms-andconditions

This article may be used for research, teaching, and private study purposes. Any substantial or systematic reproduction, redistribution, reselling, loan, sub-licensing, systematic supply, or distribution in any form to anyone is expressly forbidden.

The publisher does not give any warranty express or implied or make any representation that the contents will be complete or accurate or up to date. The accuracy of any instructions, formulae, and drug doses should be independently verified with primary sources. The publisher shall not be liable for any loss, actions, claims, proceedings, demand, or costs or damages whatsoever or howsoever caused arising directly or indirectly in connection with or arising out of the use of this material. 


\title{
Exploring the relationship between aboriginal tourism and community development
}

\author{
John W. Colton* and Kelly Whitney-Squire \\ School of Recreation Management and Kinesiology, Acadia University, Wolfville, Nova Scotia, \\ Canada B4P 2R6
}

(Received May 2010; final version received August 2010)

\begin{abstract}
Aboriginal communities are increasingly turning toward aboriginal tourism development to diversify their economic base, validate their claims related to proprietary rights over traditional lands and re-connect youth with elders and the community to their land and their culture. Oftentimes, these development initiatives are tied to broader community development goals, yet the success of the tourism project is generally measured by its market readiness, revenue generation and job creation. The purpose of this article is to provide insight into the breadth of aboriginal community development benefits from tourism development through a review of literature of selected international case studies on aboriginal tourism development. Framing our approach is Bell's typology of aboriginal community development that is conceptualized as consisting of five dimensions that include community empowerment, community wellness, community economic development, community learning and community stewardship [Bell, M. (1999). The changing face of community development in the north: From the power paradigm to the spirit paradigm. Yellowknife, NWT: Inukshuk Management Consultants]. The analysis provided insight into how aboriginal tourism initiatives benefit broader community development dimensions beyond the economic and that to develop tourism that extends its benefits to the community, issues that relate to community empowerment, wellness and healing and stewardship should be addressed.
\end{abstract}

Keywords: aboriginal community development; aboriginal tourism

En guise de diversifier leurs bases économiques, les collectivités autochtones se tournent de plus en plus vers le tourisme autochtone. Ces initiatives sont souvent liées à un développement communautaire, la revendication des droits autochtones, et le renouvèlement intergénérationnel entre les Aînés et les jeunes. Le succès de ces projets de tourisme est généralement mesuré par la volonté du marché, et la création de revenus et d'emplois. Une revue littéraire et une examinations d'études de cas internationales sur le développement du tourisme autochtone nous donnent un aperçu des allocations du développement touristique communautaire autochtone. L'encadrement théorique de cette approche vient de la typologie de développement communautaire autochtone conçu par Bell [Bell, M. (1999). The changing face of community development in the north: From the power paradigm to the spirit paradigm. Yellowknife, NWT: Inukshuk Management Consultants]. Cette typologie est composée de cinq dimensions: (i) l'autonomie communautaire (ii) le bien-être communautaire (iii) le développement économique communautaire (iv) l'apprentissage communautaire, et (v) l'intendance communautaire. L'analyse nous donne un aperçu comment les initiatives de tourisme

*Corresponding author. Email: john.colton@acadiau.ca 
autochtone vont au-delà du développement économique communautaire, et suggère que pour le développement communautaire approprié, le tourisme autochtone doit aussi engendrer les questions qui sont reliées à l'autonomie des communautés, le bien-être et la guérison, et une gestion responsable.

Mots-clés: développement communautaire autochtone; le tourisme autochtone

\section{Introduction}

Aboriginal tourism development provides many benefits, but to what extent does it develop community? Aboriginal tourism has been explored in terms of its ability to provide meaningful community economic benefits, community empowerment (Scheyvens, 1999, 2002) and community access and proprietorship to traditional lands (Zeppel, 2006). Aboriginal tourism frameworks have articulated the process of aboriginal tourism development and the role of the community (Sofield \& Birtles, 1996), the level of opportunity depending on the mix of habitat, handicrafts, heritage and history (Smith, 1996). More recently, Weaver (2009) identified six stages of indigenous tourism, which provided a useful synthesis of the evolution of indigenous tourism from pre- to post-European contact where the fifth and sixth stages revealed increasing community control and/or greater autonomy of traditional resources. Collectively, these and other studies indicate that community is the essential ingredient in aboriginal tourism and that meaningful and sustained benefits must accrue to aboriginal communities pursuing this type of development. Although studies in aboriginal tourism have articulated the types of benefits associated with tourism development and explored some of these benefits in depth (i.e. community empowerment, access/control of traditional resources), few studies have explored the breadth of community benefits derived from participating in aboriginal tourism.

The purpose of this article is to provide insight into the breadth of aboriginal community development benefits from tourism development through a review of selected international case studies on aboriginal tourism development. Framing our approach is Bell's (1999a) typology of aboriginal community development, conceptualized as consisting of five dimensions and include community empowerment, community wellness, community economic development, community learning and community stewardship. This article does not represent a state of knowledge review of aboriginal tourism development case studies; rather, it explores a sample of case studies published within the last 10 years from which to develop insights.

\section{Aboriginal tourism and community}

For the purpose of this study, community is defined as a geographic location and network of people with shared historical and cultural heritage (Hunt \& Smith, 2006). Community is characterized by strong networks of social relations that provide the ability to participate, cooperate and interact (Stone \& Hughes, 2002). The focus of recent and ongoing research in aboriginal tourism is framed around community as the critical component in tourism development and the extent to which the community is impacted either positively or negatively from tourism development. Central to this approach has been the issue of control and whether aboriginal communities have some modicum of control. Hinch and Butler's (1996) definition of indigenous tourism suggested that "Indigenous tourism refers to tourism activity in which indigenous people are directly involved either through control and/or by having their culture serve as the essence of the attraction" (p. 9). It can be assumed that if control is lacking despite the ability to showcase aboriginal culture as an 
attraction, then benefits to the community will be diminished. Building on the previous definition, Zeppel (1998) developed a more focused definition, suggesting aboriginal tourism is "tourism enterprises controlled by indigenous people," including "culture-based attractions and other tourist-oriented facilities or services" (p. 60). Control, in this definition, is the defining feature of aboriginal tourism and excludes aboriginal tourism operations, services and attractions where control is lacking. Weaver's (2009) fifth and sixth stages of the evolution of indigenous tourism is "characterised by reassertions of formal control over tourism within indigenous areas" (p. 8). Examples of this include limiting visitor access to aboriginal communities and placing restrictions on wildlife viewing and/or hunting. With greater ability to control the various inputs (e.g. natural resources, cultural activities) and outputs (e.g. visitor experiences) associated with tourism development, aboriginal communities are well positioned to transition from tourism development to community development.

Community development is driven, in part, by the degree to which community members are empowered. Reid and van Dreunen (1996) note that, "community development 'is a process for empowerment and transformation' of individuals and communities" (p. 49). Few aboriginal tourism development studies focus on the role of empowerment, yet to realize broader community development benefits, the community members must be empowered. Largely discussed within development theory, empowerment can be defined as

A process whereby [people] become able to organize themselves to increase their own selfreliance, to assert their independent right to make choices and to control resources which will assist in challenging and eliminating their own subordination. (Keller \& Mbewe, 1991, p. 76)

Scheyvens (1999) explored the concept of empowerment in relation to ecotourism development and proposed a framework that was inclusive of broader social dimensions within the community. In this framework, economic, psychological, social and political dimensions of empowerment were highlighted. As a framework for analysis, this perspective has proven useful. For example, Sandmeyer (2005) used Scheyven's framework to examine the broader implications of community-based tourism among the Kitasoo/Xaixais First Nations in British Columbia, Canada. The move toward examining the broader implications of tourism development on the community is a significant shift in both theory and practice. Supporting this shift has been a reliance on other scholarly perspectives (i.e. dependency theory) generally not relied upon in tourism studies. This trend is continued in this article as the analytical lens through which to examine the broader community implications of tourism development and is drawn from aboriginal community development scholars.

\section{Aboriginal community development}

Traditionally, community development in aboriginal communities has focused on economic development in the form of job creation, economic diversity and income generation. Controlled largely by external forces such as government and corporations, this type of development has most often failed (Cornell \& Kalt, 1990, 1998; Elias, 1991, 1997; Eversole, 2003) and normally does not lead to long-lasting prosperity. More recently, aboriginal peoples are pursuing a comprehensive approach to community development that is more holistic (Elias, 1991; Royal Commission on Aboriginal Peoples, 1996). Through this approach to development, elements of culture, community healing, traditional practice and empowerment are highlighted. 
Bell (1999a), a community development consultant and scholar in the Canadian north for the past three decades, suggests that the focus of development be on relationships rather than on place. This is a departure from traditional approaches to aboriginal community development that produced as a by-product learned helplessness where community residents become accustomed to service delivery based on needs (Bell, 1999a; Warry, 2000). By emphasizing development that builds healthy relationships, Bell (1999a, 1999b) extends Kretzmann and McKnight's (1993) Asset-Based Community Development approach, which focuses on capacity building and local assets by acknowledging the importance of a development paradigm that seeks to restore the relationships broken in aboriginal communities by generations of oppression. Without healthy relationships informed by healing, capacity building opportunities and a strong connection to culture and the land, development of any kind, including tourism, will likely be unsustainable. Based on these principles, Bell (1999a) outlined a framework for considering aboriginal community development. The factors, which underpin this framework, include community empowerment, community wellness, community economic development and community learning (see Table 1).

The foundation of community wellness rests on a community's ability to establish, foster and maintain healthy, balanced relationships individually and collectively within the context of their land and culture (Bell, 1999a). Bell postulated that in the absence of wellness, there could be no real or sustainable development within aboriginal communities. The premise for this statement being that although aboriginal people recognized the need for economic development and the importance of empowerment, there was an awareness and acknowledgement that without what Bell refers to as "Community Healing" any efforts expended to establish successful, long-term development projects were effectively doomed. Few studies in aboriginal tourism have focused on the issue of healing

Table 1. Aboriginal community development framework.

\begin{tabular}{ll}
\hline Community empowerment & \multicolumn{1}{c}{ Community economic development } \\
\hline - Governance & - Jobs and job development \\
- Community control & - Business \\
- Organization structures & - Investments \\
- Representation & - Community economic development strategies \\
- Programs and services & - Models, partnerships and support mechanisms \\
- Resources & \\
- Policy frameworks & \\
- Links with other organizations & \\
\hline Community wellness & \\
\hline - Physical, mental and spiritual health & - Community as classroom \\
- Relationship with the land & - Land as a classroom \\
- Self-identity through traditional culture & - Acquiring wisdom from elders \\
- Healing & - Schooling \\
- Prevention & - Lndividual and group learning \\
- Supportive relationships & - Skill development and training \\
- Links between personal and family needs, & \\
- Strong families &
\end{tabular}

Source: Bell (1999a). 
yet most indigenous societies worldwide have experienced various forms of oppression, colonization and economic marginalization.

Community economic development has been subject to extensive academic review, particularly relating to tourism development (Bell, 1999a; Butler \& Hinch, 2007; Parker, 1993; Telfer, 2002) and aboriginal economic community development (Cornell \& Kalt, 1990; Elias, 1991, 1997). The creation of community-based economies is often the driving force behind tourism development. The type of development, the location and stakeholders involved might change, but the goal of creating employment, local business and investment opportunities is a constant (Bell, 1999a). Broadly encompassing this goal is the formation of the models, mechanisms, institutions and strategies needed to support and encourage continued economic growth in aboriginal communities (Bell, 1999a; Cornell \& Kalt, 1998). Governments have promoted economic initiatives as the key ingredient in successful aboriginal community development. Cornell and Kalt's (1998) research states that the "jobs and income" approach, which looks at only the economic side of the equation of community development, seldom produces lasting economic prosperity.

Given the historical backdrop of assimilation and suppression of aboriginal peoples, the process of recapturing the inherent relationships necessary for community learning is complex (Colton \& Harris, 2007). Aboriginal community learning is broad in that it encompasses many facets of the people such as cultural knowledge, social knowledge and traditional knowledge, which in turn encompass their relationship to the spiritual and natural environment (Bell, 1999a; Colton, 2005). Community learning is necessary to build capacity and to empower individuals and communities, which will support and sustain economic development initiatives (Bell, 1999a; Colton, 2005; Simpson, 2005; Simpson, Wood, \& Daws, 2003).

Bell (1999b) argues that aboriginal people's relationship to the land is a critical factor as well in considering aboriginal community development. He suggests this intangible bond or connection to the land is made tangible through the primary relationships of spirituality, traditions, culture and social structures within the aboriginal community (Bell, 1999a; Berry, 1988). Harris (2009), using Bell's framework for aboriginal community development to examine the relationship between ecotourism and community development in a Mik'maq community in eastern Canada, suggested that Bell's framework include an additional dimension related to stewardship. Given the intersection between community and the integral relationship to the land from which culture and traditions emerge, and heeding the suggestion of Harris (2009), a fifth dimension is added to the framework labelled community stewardship. Therefore, the five focal points from which to explore the breadth of community development benefits derived from aboriginal tourism development are community empowerment, community wellness, community economic development, community learning and community stewardship. The different factors of the framework do not exist in isolation, but interact and contribute to the complexity of relationships and community development.

\section{Methods}

An analysis of 21 scholarly articles on aboriginal tourism development was conducted. Bell's (1999a) framework served as a filter for the initial selection of articles. Thus, articles on aboriginal tourism development that addressed aboriginal community development issues related to Bell's key themes (i.e. community empowerment, community wellness, community economic development, community learning and community stewardship) were 
included in the initial selection of articles. Other criteria for selection included aboriginal tourism development projects reported in tourism and aboriginal community development scholarly journals; case study type reporting methods that provided significant information on the aboriginal tourism development project and publication dates from 1999 to 2009 in an effort to capture recent aboriginal tourism development projects. While the case studies represent an assortment of development contexts (i.e. community based, communityNGO based, community-NGO-government based, community-government based) from a number of countries, important lessons can be drawn from exploring the relationship of aboriginal tourism development and community development.

Articles were reviewed and analyzed in light of the aboriginal community development framework (i.e. community empowerment, community wellness community economic development, community learning and community stewardship). In the initial review of each article, community development benefits were placed in one or several of the five aboriginal community development categories. These were reviewed and modified independently by each author until a final table emerged of the community development benefits that pertained to a specific dimension. A third review of each aboriginal community development dimension refined the category into sub-themes, which was reviewed independently by each author. Based on this strategy, a final table emerged that articulated the community development benefits derived from aboriginal tourism development from the selected case studies.

\section{Exploring aboriginal tourism and community development}

The following discussion explores the types of community development benefits derived from aboriginal tourism development. Although the aboriginal community development framework provided a specific way in which to organize the findings, sub-themes emerged from each dimension that offered clearer insight into how tourism impacts community development. Table 2 provides a backdrop upon which to view the various categories that emerged from the research.

Table 2. Aboriginal tourism and community development benefits.

\begin{tabular}{lc}
\hline Community empowerment & Community economic development \\
\hline - Community ownership & - Community/family entrepreneurship and aboriginal \\
- Leadership and governance & owned/operated \\
- Community input & - Income generation and economic diversity \\
- Legal foundations & - Investment in culture and people and funding for \\
- Relationships & non-tourism initiatives \\
& - Partnerships/strategic planning and investment \\
\hline
\end{tabular}

Community wellness

Community learning

- Physical/social benefits

- Organizational benefits

- Support for tradition/culture

- Community cohesion
- Cross-cultural learning

- Renew/strengthen culture

- Aboriginal informed management practices

- Capacity building/experience/skills

- Value and role of tourism

Community stewardship

- Environmental stewardship

- Culturally informed management practices 


\section{Community empowerment}

Working from the perspective of community-based aboriginal tourism development, empowerment not only becomes the fundamental and practical process of gaining control over projects, but offers socially and culturally based opportunities that support contemporary and traditional ways of life. The literature review supports these statements in that relationships can be drawn between the broader concept of empowerment and the benefits or outcomes of activities and actions by individuals and the community at large. These benefits breakdown into four sub-categories: community ownership/input, leadership and governance, legal foundation and relationships.

\section{Community ownership and input}

The local ownership of projects, organizations, committees, volunteer groups, co-operatives and businesses are a central component of many of the tourism ventures reviewed (Li, 2006; Mitchell \& Eagles, 2001; Salole, 2007). In Nunavut, aboriginal rights on polar bear hunting are affirmed by international agreements and guiding and outfitting is under local aboriginal control (Dowsley, 2009). In the Annapurna region of Nepal, communities have developed a governing body to promote conservation and manage tourism sustainably (Nepal, 2007). In Zambia, prior to intensive tourism development, indigenous communities sought and gained legal tender to the land and developed policies that supported local control and family involvement in tourism development (Mvula, 2001). Through these activities, communities individually and collectively support empowerment processes, but also social and cultural factors that foster long-term development and growth.

The individual contribution of any one component may be small, but taken together they are representative of the types of activities that build relationship capacities within communities. At best they are the culmination of activities that put "people at the centre of development efforts and initiatives" (Nepal, 2007, p. 238). Communities have developed myriad ways of encouraging community input and participation such as mandatory volunteer service, communal labour, consensus decision-making, creation of working groups, equitable distribution of benefits/work and involvement of elders (Dowsley, 2009; Mitchell \& Eagles, 2001; Nepal, 2007; Nyamweru \& Kimaru, 2008).

\section{Leadership and governance}

Communities that have enjoyed a measure of success in building tourism projects have one or more aspects of leadership and governance in common. Specifically, long-term strategic plans have been developed; strong informal decision-making processes have been utilized (Colton \& Harris, 2007; David, 2009); a number of locally based governing agencies, organizations and institutions/associations have been developed (Harris, 2009; Mvula, 2001), and accessed monetary means through grants and are fully accountable for expenditures. The Lennox Island Ecotourism Strategy developed by the Lennox Island First Nation in Prince Edward Island, Canada, was a 10-year strategy that specifically outlined decisionmaking processes including frameworks for transparency that have limited the potential for conflict among community members in Lennox Island. The Torra Conservation Area in Namibia developed adjudicating committees and processes to mitigate conflicts of interest (Salole, 2007). Leadership and governance associated with tourism ventures is a critical factor as the benefits of development are normally distributed, in part, through a governance 
structure. Transparency also ensures good will and supports community relationships (Colton \& Harris, 2007).

\section{Legal foundations}

Community-based tourism projects have facilitated the recognition of aboriginals' legal right to hunting, fishing and the protection of reserves or traditional lands from encroachment. This, in part, has been accomplished through some areas receiving designation as world heritage sites, protected biospheres/nature reserves, and through national and international negotiated settlements and agreements (Dowsley, 2009; McGinley, 2002; Nyamweru \& Kimaru, 2008). The ability to obtain rights over communal land; a growing awareness of personal and collective rights (Salole, 2007); the incorporation of bands and the establishment of protections for ownership of art/images, stories and ancestors has allowed some communities to move toward greater autonomy over local resources (Colton, 2005).

Some aboriginal communities have established protocols for ownership of culture, history and language; drafted constitutions to structure interactions between participating communities with equal representation and established governing bodies to regulate conservation and tourism (Vodden, 2002). They are being empowered through the use of traditional and new power strategies (Nepal, 2007), and, in some cases, they have refused to accept funds/advice from government authorities as a means of ensuring control (Hipwell, 2007). Aboriginal groups in the Wet Tropics Rainforest of Queensland, Australia, are being helped by the fact that some major industry players recognize aboriginal ownership of art/images (Sofield, 2002) and investment in aboriginal art/culture can be a vehicle for economic and community development.

\section{Relationships}

Community-based tourism projects are grounded in the traditional and new relationships being formed to carry out development initiatives. The essential element of empowerment here is that relationships clearly support the cultural and social values inherent in aboriginal traditions (Colton, 2005). At the same time, they support the fundamental and practical processes necessary to any development initiative, such that it keeps people at the heart of development (Nepal, 2007). While relationships are critical to empowerment, it is important to note that healthy relationships are a foundational element within Bell's framework.

\section{Community wellness}

Aboriginal tourism as a mechanism for community development can be utilized as an effective means of fostering community wellness and within this context, the literature review established that the positive impacts or benefits of tourism development are extensive and broadly based. In evaluating the impact of community-based aboriginal tourism development on community wellness, the accruement of benefits is set in motion in two ways: (1) tourism activities and processes that necessitate the building of stronger relationships and (2) community relationships that foster the building of tourism activities and processes. These benefits will accrue incrementally and in parallel to one another in a way that reflects the dynamics of this process (Bell, 1999a). Within this context, benefits impacting community wellness, although rooted in the individual and inter-relationships 
being formed, typically fall into one of four sub-categories: physical/social; organizational; traditional/cultural and community cohesion.

\section{Physical and social benefits}

These types of impacts reflect a very real or concrete benefit to individual residents and the community at large. They include an improved standard of living and poverty reduction in addition to improved community infrastructure (Cave, Ryan, \& Panakera, 2007; David, 2009; Harris, 2009; Mvula, 2001; Nyamweru \& Kimaru, 2008). For example, the building of trail systems and recreation facilities for visitors has the additional benefit of providing improved leisure and recreation opportunities for residents (Colton \& Harris, 2007; Vodden, 2002). Many communities build cultural centres to support tourism development initiatives, but underlying the obvious use of these types of facilities is the fact that they become a focal point of community expression and an avenue for developing healthy individual and inter-relationships within the community.

Tourism development brings support for building social and community activities through local community groups, ceremonies and projects (David, 2009; Harris, 2009; Li, 2006; Mitchell, \& Eagles, 2001; Mvula, 2001; Nepal, 2007; Nyamweru \& Kimaru, 2008). Whereas traditional ceremonies may be held for the enjoyment of visitors, the involvement and opportunity for community members to organize and perform becomes another avenue for the development and support of relationships by creating meaningful opportunities to learn important traditional practices. Several communities are utilizing a portion of tourism revenues and fees to support secondary social projects such as schools, youth camps, water wells and cultural centres (Mitchell \& Eagles, 2001; Nepal, 2007; Nyamweru \& Kimaru, 2008). Specifically, tourism development at the St. Eugene Resort in British Columbia has been the catalyst, in part, to develop cultural camps for aboriginal youth (David, 2009). Resort development has also included the development of the residential school into a cultural centre that allows community members and visitors to better understand the role of these institutions in the lives of aboriginal people.

\section{Organizational benefits}

Many communities have implemented internal organizations and committee systems to help deal with the realities of tourists coming into their communities. Hosting and greeting visitors, establishing mechanisms for the equitable distribution of benefits and the sharing of resources have necessitated that local people work together (Nepal, 2007; Vodden, 2002). Many have come up with unique and innovative ways to ensure fairness and equity in their dealings. Consensus price setting, committee processes for the standardization and approval of accommodation and various fee structures and mechanisms aimed at spreading the benefits of tourism as broadly as possible (Hipwell, 2007; Mitchell \& Eagles, 2001) are examples of the strategies used by aboriginal communities to promote fairness and equity.

These communities demonstrate a broad level of support for tourism development and an acceptance of what development will bring (Li, 2006; McGinley, 2002). The level of community participation in the decision-making process becomes the building blocks for broad community support and is itself another avenue for developing healthy relationships (Vodden, 2002). Organized management and the assumption of corporate responsibility for tourism activities such as clean-up and maintenance are indicative of a community working together in a manner that can only stem from shared goals and a common purpose (Nepal, 2007). 


\section{Support for tradition/culture}

Healthy, balanced relationships within the community are reflected in the way tourism development projects build on the strengths already inherent within the community's traditions of equality, social structure, connection to the land and spirituality. These strengths culminate in ceremonies, dancing, drumming, singing, language, medicines, lifestyles and sacred places (Dowsley, 2009; Notzke, 2004; Vodden, 2002; Wang \& Wall, 2005).

Communities whose tourism development activities reflect chosen cultural appropriateness and authenticity and who have input and control over its presentation develop tourism products and services that are highly reflective of the people (Cave et al., 2007; Dyer, Aberdeen, \& Schuler, 2003; Wi'la'mola Project, 2009). The process is mutually beneficial and the positive promotion and preservation of artifacts, stories and skills for future generations encourages positive self-worth, pride and respect for elders (Liu, 2006; Sofield, 2002). Participating in aboriginal tourism celebrates the history, future, identity, heritage and traditional knowledge (Salole, 2007; Sofield, 2002; Wang \& Wall, 2005).

\section{Community cohesion}

Many of the tourism projects reviewed served to reinforce that collective community good was accomplished through tourism projects that provided greater opportunities for collaborative action, fostered a sense of community pride, served to support the development of youth and encouraged personal development and a greater sense of community. For example, on Taquile Island, Peru, the community has implemented several initiatives such as consensus pricing that require them to "set aside gratification in order to preserve the unity of the group" (Mitchell \& Eagles, 2001, p. 21). Three First Nation Bands of British Columbia found a way to create a new legacy of remembrance for their youth by transforming the old residential school into the St. Eugene Resort and Casino that houses a cultural centre (David, 2009). These communities, small and large, take great pride in their people and their accomplishments. The Torra Conservancy in Namibia, Whale Watch in New Zealand and $\mathrm{KuKu}$ Yalanji Dream Time Tours of Australia have all won national and international awards for their collaborative community developed tourism operations (Curtin, 2003; Salole, 2007; Sofield, 2002).

\section{Economic development}

Economic benefits flowing to aboriginal communities developing tourism reflect various sub-themes that include community/family entrepreneurship; aboriginal owned/operated; income generation; economic diversity; investment in culture and people; funding for nontourism initiatives and partnerships/strategic planning and investment.

\section{Community/family entrepreneurship and aboriginal owned/operated}

Community and family involvement with business development was widespread in the case studies. Family groups have developed business cooperatives, shared business ownerships and integrated management systems to support local entrepreneurship (Mitchell \& Eagles, 2001; Nyamweru \& Kimaru, 2008). Examples include local weavers on Taquile Island, Peru, who have formed community stores, charter boat services, transportation services and family/group ownership of restaurants and cafes (Mitchell \& Eagles, 2001). Groups in Alert Bay and Lennox Island have developed cultural/adventure tourism, sea kayaking, trekking and hunting excursions, in addition to creating other local and aboriginal tourism 
products (Colton \& Harris, 2007; Vodden, 2002). The Tsou people in Taiwan have created a successful performance hall, a collection of food stands and open-air restaurants at the Tanayiku Natural Ecology Park (Hipwell, 2007). Furthermore, many businesses or projects are fully owned and operated by the community or band/tribe and include developments such as Kaikoura WhaleWatch in New Zealand (Curtin, 2003) and those undertaken by the Buffalo Point First Nation in southern Alberta, Canada (David, 2009).

\section{Income generation and economic diversity}

Many aboriginal communities reported tourism as a major economic contributor to the region (Annapurna), (Nepal, 2007), and bring in significant tourism dollars (Jiuzhaigou Biosphere Reserve) (Li, 2006). Job stability, local recruitment and local service recruitment were noted as other benefits of aboriginal tourism development (Wang \& Wall, 2005). Kaikura's WhaleWatch estimates that over $70 \%$ of the aboriginal community are involved in tourism and that a full 1/4 of all jobs are directly related to tourism (Curtin, 2003). For others, tourism development became a source of non-government money. In Nunavut, tourism development provides direct economic benefits to guides and outfitters involved in polar bear hunting (Dowsley, 2009). Aboriginal tourism development brings foreign exchange into areas such as communities adjacent to Luangwa National Park in Zambia (Mvula, 2001) and for generating forms of income other than wages in most case study aboriginal communities. For example, in the Jiuzhaigou Biosphere Reserve in China, a portion of the fees that tourists pay (park entrance fees) goes back to the locals on a monthly basis to directly support conservation efforts ( $\mathrm{Li}, 2006)$. There is an awareness that economic diversity is important to success (Vodden, 2002), and communities have implemented administrative structures through tourism that support expansion and diversification of the local economy (McGinley, 2002).

\section{Investment in culture/people and funding for non-tourism initiatives}

With strong relationships to wellness and empowerment, economic revenues are being utilized to support cultural ceremonies, community projects such as the construction of cultural centres, improved housing standards, trail development and many others initiatives (Colton \& Harris, 2007; Liu, 2006). For example, by investing tourist dollars in seemingly non-tourism related initiatives such as community website development, Alert Bay, BC, Mistissini, Quebec, and Sarawak, Malaysia, are showcasing their communities, improving communication systems and increasing their accessibility (Harris, 2009; McGinley, 2002; Vodden, 2002). Improvements, even the most basic, bring needed services for visitors and locals alike such as electricity and telephones to Mfuwe, Zambia (Mvula, 2001), water access and trails to the people of Kaya Kinondo, Kenya, (Nyamweru \& Kimaru, 2008) and funding for community development projects such as schools and clinics in the Kakumbi/Nsefu region of Zambia (Mvula, 2001). In recognizing opportunities for the community through tourism (Salole, 2007; Vodden, 2002), initiatives that support cultural development through the use of tourist and non-tourist economic resources build awareness of the attraction and the destination.

\section{Partnerships/strategic planning investment}

Community economic development has necessitated the creation of corporations (David, 2009), the use of marketing cooperatives and partnering opportunities and the 
implementation of long-range strategic development plans to engender success by communities such as the James Bay, Cree Nation of Mistissini (McGinley, 2002). Large and small communities have developed long-range plans for growth/expansion (Liu, 2006) and are utilizing a number of strategic development options such as the lease back of land to create successful businesses (David, 2009), and for those who are able, such as the Buffalo Point First Nation of Alberta, the leveraging of funds to access capital. Others take advantage of the opportunities through regional tourism development initiatives (Mitchell \& Eagles, 2001) and participate in joint investment and marketing initiatives (McGinley, 2002; Wang \& Wall, 2005).

\section{Community learning}

In evaluating the types of learning that occur as a result of community-based aboriginal tourism, the literature review highlighted the benefits that support the inherent relationships needed to re-capture the knowledge of the people. Each of the following sub-categories impacts on one or more aspect of community learning: renew/strengthen culture; aboriginal informed management practices; build capacity; cross-cultural learning and value/role of tourism.

\section{Renew/strengthen culture}

Aboriginal tourism projects have provided increased opportunities for the promotion of traditional learning forms and styles, the transfer of skills and knowledge from elders to youth, and brought support for the education of children (Colton \& Harris, 2007; Sofield, 2002; Wang \& Wall, 2005). Communities have found that youth are being encouraged to learn traditional and ecological skills and language (Dowsley, 2009). Examples would include the sewing of skin clothing, dog sledding and traditional camps (Dowsley, 2009; Dyer et al., 2003). New learning has resulted from situations arising from tourism development issues, but has in some cases found a culturally appropriate response. For example, in Kenya, although wealth stratification has always existed, elders are becoming more aware of increased wealth stratification through tourism development (Nyamweru \& Kimaru, 2008), and how they and the community should respond to rising community tension over this issue.

\section{Aboriginal informed management practices}

Aboriginal communities are taking on leadership roles in the advancement of their communities and environment. In the form of appropriate management practices, a reciprocal process of learning has inspired the implementation of restrictions on access to visitors, which has served to increase visitor respect and appreciation for their experience (Nyamweru \& Kimaru, 2008). Examples include the Kaikoura WhaleWatch in New Zealand, which has developed and implemented codes of conduct for visitors and operators alike that are being followed, in addition to the enforcement of regulations and licensing requirements (Curtin, 2003). Another specific example is the Kaya Forest in Kenya where there is awareness that cultural restrictions have increased visitor appreciation for the special nature of the forest (Nyamweru \& Kimaru, 2008). These management activities encourage ecologically and culturally sound practices and local support for scientific research practices as found by the Inuit of Nunavut in regard to the sport hunting of polar bears (Dowsley, 2009). 


\section{Build capacity (experience/skills)}

Many aboriginal communities have benefited as a result of the educational opportunities brought about by tourism development. The building of local capacities and individual and corporate relationships has resulted in part from the experiences and skills gained through youth training, outdoor leadership, guiding and conservation management (Colton \& Harris, 2007; Mvula, 2001; Vodden, 2002). Tourism has provided increased opportunities and community members are taking advantage of learning situations by becoming members of park boards; , participating in negotiation processes and working with government, local business and residents (Curtin, 2003; Dyer et al., 2003).

It is the practical application of these skills and abilities that have allowed communities to gain related management experience in tourism marketing, infrastructure requirements, feasibility studies, entrepreneurship, investment opportunities, socio-economic development and research (Harris, 2009; McGinley, 2002; Salole, 2007; Wang \& Wall, 2005). The types of learning are broad, formal and informal, and all contribute to the cultural, social and traditional knowledge systems at work within the community (Bell, 1999a; Liu, 2006).

\section{Cross-cultural learning and the value/role of tourism}

Through the development of community-based tourism projects, aboriginal people are finding opportunities to share certain aspects of their cultural, social structure, and environment with visitors and others. In many instances, tourism provides a shared learning experience for visitors and hosts alike such as the Lennox Island First Nation, where learning promotes acceptance between native and non-native (Colton \& Harris, 2007). Tourism increases visitor awareness of the environment and that of natural resources (Mvula, 2001; Wi'la'mola Project, 2009) and contributes to reducing assumptions and stereotypes held by visitors (Colton \& Harris, 2007; Notzke, 2004). An awareness of the value of community-based tourism development becomes more apparent as "tourism awareness" is being incorporated into the planning process for locals (Mitchell \& Eagles, 2001). This growing awareness increases the level of local support in consideration of the benefits and potential to be had through tourism development (McGinley, 2002; Mitchell \& Eagles, 2001; Mvula, 2001).

\section{Community stewardship}

Bell (1999b), whose research and long experience working with northern groups of aboriginal people, postulated that it is their bond or relationship with the land that has enabled them to survive centuries of suppression and oppression. To borrow on Bell's thinking, community stewardship can be defined as any action or initiative that strengthens their primordial, intangible relationship to the land. Given this definition, the case study review is telling for the fact that regardless of the community involved, relatively few noted any benefits that linked the people to the land in this way. Of the 21 case studies, 11 articles made little or no reference to land-based benefits, 8 focused predominantly on environmental stewardship and 2 focused on culturally informed management practices.

\section{Environmental stewardship}

Stewardship of the environment involves both traditional approaches (i.e. protected areas and reserves) and community-based approaches. Community-based aboriginal tourism developments have been helped by the protection of lands through the establishment of 
national parks such as the Pulong Tau in Malaysia (Harris, 2009), the isolation of some areas from mainstream populations such as Nunavut (Bell, 1999b) and the creation of conservation projects such as the Mistissini Lake Fish Project (McGinley, 2002). Communities have also benefited from the receipt of outside funding for wildlife protection and conservation activities as in the Luangwa National Park in Zambia (Mvula, 2001) and the communities of Chale and Mngwai in Kenya (Nyamweru \& Kimaru, 2008).

Benefits have also accrued to communities as a result of an increased desire to prevent environmental degradation (Hipwell, 2007) and a growing concern for sustainability (Curtin, 2003). Residents have experienced tourism projects as having directly lessened damage to the environment through the implementation of restrictions on motor vehicle access (Li, 2006), visitor access to sacred sites/fishing (Hipwell, 2007), and the use of local guides and guards to patrol against destruction and damage (Nyamweru \& Kimaru, 2008; Sofield, 2002). The most telling benefit is that communities see themselves as "ecological stewards" (Hipwell, 2007), with the ability to foster a long-term commitment for the purpose of conservation and preservation (Curtin, 2003; Salole, 2007). In the case of inhabitants of the Daintree Coast, Australia, they have found that tourism initiatives support their belief that nature and culture cannot be divided or viewed separately (Sofield, 2002). Practices to support the revitalization of cultural identity would include the use of indigenous guides and the interpretation and presentation of the natural and the cultural to visitors (Solfield, 2002). These practices strengthen traditional, cultural and social primary relationships.

\section{Culturally informed management and conservation}

Tourism encourages "community-centred" resource management and benefits relate to the implementation of management practices that are rooted in cultural practices, traditions and beliefs. In Kenya, Kaya guards protect the forest, which is viewed as sacred by the community and for many parts of the forest; tourism is restricted due to areas of community significance (Nyamweru \& Kimaru, 2008). In Nunavut, popular for sport hunting (e.g. polar bears), only $20 \%$ of allowable tags are turned over to commercial hunters (Dowsley, 2009). Similar practices in New Zealand occur with limited use of available whale watching permits in order to protect the resource (Curtin, 2003).

\section{Discussion and conclusion}

Although the case studies in aboriginal tourism are contextually unique, insight is offered into the role of aboriginal tourism and community development. Based on this cursory review, it can be suggested that aboriginal tourism development supports community development in the broad dimensions associated with Bell's framework (i.e. community empowerment, community wellness, community economic development, community learning and community stewardship). The case studies demonstrate that community development benefits are extensive and collectively support the relationships necessary to sustain tourism development. While no hierarchy has been articulated with respect to Bell's framework, the role of community empowerment is critical to supporting other benefits across these dimensions. Bell's framework, in this context, demonstrates the breadth of aboriginal community development benefits, but the research did not necessarily demonstrate the depth and the extent to which these benefits are enduring. Nor did the research explore to what extent the community development benefits were intentionally planned for or not. Further research is required to better understand how to plan for benefits that directly support community empowerment, wellness and learning. 
Analysis of the case studies suggests that aboriginal communities were empowered through their involvement in tourism development. Positive relationships in the community were reinforced with opportunities to participate in decision-making, the ability to directly influence the direction of tourism development and the opportunity to exercise aboriginal rights over traditional lands. While these examples reflect the results of tourism development, they also demonstrate the role of tourism in acting as an agent of community empowerment. Self-reliance, the ability to control resources and greater opportunities to eliminate their own subordination (Keller \& Mbewe, 1991) are benefits that will extend beyond the experience of developing tourism.

Community wellness, community economic development and community learning were outcomes associated with the ability to control resources, plan and develop tourism, and participate in forms of governance that highlighted transparency. Examples of benefits within these dimensions (i.e. community wellness, community economic development and community learning) demonstrate the ability of tourism development to offer opportunities for culturally relevant activities that strengthen and renew culture and provide meaningful opportunities for economic engagement. While the focus is most often on community economic development, Bell's framework denotes the importance of these two other dimensions of equal significance. Yet discrete community benefits are rarely planned in regard to community wellness and learning and are most often unintentional by-products (Colton \& Harris, 2007) of an overall tourism development strategy. The importance of recognizing, valuing and planning for benefits associated with community wellness and learning is critical to supporting healthy relationships that are foundational to Bell's framework. Given the fact that most tourism ventures of any kind fail in their first few years of operation (particularly aboriginal tourism ventures), aboriginal communities, tourism practitioners and scholars should seek to better integrate aspects of community wellness and learning in their tourism development strategies.

An essential ingredient to the flow of benefits to the community was the degree of control exercised by the aboriginal communities. Examples of this include the development of governing structures, polices and processes that managed the flow of inputs and outputs associated with tourism development. Other factors demonstrate control as well, including the ability of communities to manage their identity and message through websites and other marketing initiatives. Of greater significance were examples of aboriginal land tenure and proprietorship that enabled the development of culturally informed land management practices such as restrictions and polices related to polar bear hunting in Nunavut. The issue and importance of control in aboriginal tourism development is no surprise given the important insights developed in the literature (e.g. Hinch \& Butler, 1996; Zeppel, 2006). Yet as Sandmeyer (2005) suggests, "community control vis-à-vis tourism . . . does not implicitly lead to community development as much as it mitigates negative externalities" (p. 130). Further research into what is often overlooked is the method for the distribution of benefits in a community. Whereas aboriginal communities may direct the flow of benefits to the community, inequitable distribution of these benefits may occur. Typically, benefits flow to people most capable of capitalizing on opportunities, marginalizing community members traditionally disenfranchised. Resentment and tension within the community therefore can grow, which can result in negative visitor experiences and a diminishment in the flow of benefits.

Scheyvens $(1999,2002)$ explored the concept of empowerment as consisting of several dimensions that include economic, psychological, social and political. Unlike Bell's categorization of empowerment as just one element of his aboriginal community development framework, Scheyvens viewed empowerment as the broad umbrella under which the other important elements of community development rest. Both frameworks have merit 
and rather than distinguishing one as better than the other, it is more useful to note how each contributes to the discussion of the role of aboriginal tourism and the accruement of community benefits. Most notably, Scheyvens' (1999) work has been significant in the study of tourism as one of the recent frameworks from which to explore the dimensions of community development benefits. This work has mirrored the emergence and recognition of the importance of community control in relation to aboriginal tourism development studies (e.g. Hinch \& Butler, 1996) and collectively the concepts underscore the emergence in aboriginal communities of self-determination.

The value of Bell's (1999a) framework is to highlight the types of benefits possible and to underscore their importance in supporting and sustaining healthy community relationships necessary to sustain tourism development in aboriginal communities. Bell (1999a, 1999b) developed his framework from years of practical experience in the Canadian north as a community developer and consultant. One could reasonably argue that the basis for the development of this framework is too contextual (northern Canada) and therefore not applicable to other experiences. Yet, given the fact that aboriginal people worldwide share common experiences with respect to oppression, policies of assimilation and even genocide in some cases, his framework allows a more structured perspective on an exploration of the breath of community development benefits from tourism development.

Of greater significance is the umbrella under which Bell's framework rests - relationships, or more precisely, healthy relationships. The power of Bell's framework is in articulating whether these relationships exist or are developed in the context of tourism and community development. Development projects (i.e. tourism-based) that fail to address and support community relationships will likely be unsustainable and provide little community benefits except short-term economic benefits to those people best positioned to receive them. Aboriginal tourism research projects and the ways in which they are disseminated offer little insight into the nature and power of relationships in aboriginal communities. Yet, it is the strength of an aboriginal community's relationship with itself, culture and history that makes it resilient, ultimately empowered and capable of exercising control over its own destiny.

Further empirical study into the practical applications of Bell's framework could provide aboriginal communities with a strategic community development-planning tool that explores the health and stability of community relationships with respect to the dimensions of the framework. A tourism-based community development strategy that acknowledges the value of these relationships can seek development options that enhance and support them with respect to empowerment, wellness, learning and community stewardship. This presents an opportunity for aboriginal tourism scholars to develop deep and meaningful collaborative research opportunities with aboriginal communities. From this collaboration, premised on strong healthy relationships, aboriginal communities will be better positioned to take advantage and sustain economic development opportunities associated with tourism and other types of development.

\section{References}

Bell, M. (1999a). The changing face of community development in the north: From the power paradigm to the spirit paradigm. Yellowknife, NWT: Inukshuk Management Consultants. Retrieved September 2009 from http://www.inukshukmanagement.ca/Community\% 20Development\%20Essay\%2099.pdf

Bell, M. (1999b). Creating public government in Nunavut - The life place model. Yellowknife, NWT: Inukshuk Management. Retrieved September 2009 from http://www. inukshukmanagement.ca/Life-place\%20Model\%20final.pdf 
Berry, T. (1988). The dream of the earth. San Francisco, CA: Sierra Club Books.

Butler, R., \& Hinch T. (2007). Tourism and indigenous people: Issues and implications. Burlington, MA: Elsevier.

Cave, J., Ryan, C., \& Panakera, C. (2007). Cultural tourism product: Pacific island migrant perspectives of New Zealand. Journal of Travel Research, 45, 435-443.

Colton, J., \& Harris, S. (2007). The role of ecotourism in aboriginal community development: The case of Lennox Island, PEI. In R. Butler \& T. Hinch (Eds.), Tourism and indigenous peoples: Issues and implications (pp. 220-233). Burlington, MA: Elsevier.

Colton, J.W. (2005). Motivations for indigenous tourism development in northern Canada. Journal of Canadian Native studies, 15, 173-192.

Cornell, S., \& Kalt, J.S. (1990). Pathways from poverty: Economic development and institutionbuilding on American Indian reservations. American Indian Culture and Research Journal, 14(1), 89-125.

Cornell, S., \& Kalt, J.S. (1998). Sovereignty and nation-building: The development challenge in Indian country today. American Indian Culture and Research Journal, 22(3), 187-214.

Curtin, S. (2003). Whale-watching in Kaikoura: Sustainable destination development? Journal of Ecotourism, 2(3), 173-195.

David, J. (2009). Economic development success stories. SAY Magazine (Canadian), 28, 24. Retrieved August 2009, from Sport Discus.

Dowsley, M. (2009). Inuit-organised polar bear sport hunting in Nunavut territory, Canada. Journal of Ecotourism, 8(2), 161-175.

Dyer, P., Aberdeen, L., \& Schuler, S. (2003). Tourism impact on an Australian indigenous community: A Djabugay case study. Tourism Management, 24, 83-95.

Elias, P.D. (1991). Development of Aboriginal people's communities. North York, ON: Captus Press.

Elias, P.D. (1997). Models of aboriginal communities in Canada's north. International Journal of Social Economics, 24(11), 1241-1255.

Eversole, R. (2003). Managing the pitfalls of participatory development: Some insight from Australia. World Development, 31(5), 781-795.

Harris, R. (2009). Tourism in Bario, Sarawak, Malaysia: A case study of pro-poor community-based tourism integrated into community development. Asia Pacific Journal of Tourism, 14(2), 125135.

Hinch, T., \& Butler, R. (1996). Indigenous tourism: A common ground for discussion. In R. Butler \& T. Hinch (Eds.), Tourism and indigenous peoples (pp. 3-19). London: International Thomson Business Press.

Hipwell, W. (2007). Taiwan aboriginal ecotourism: Tanayiku natural ecology park. Annals of Tourism Research, 34(4), 876-897.

Hunt, J., \& Smith, D. (2006). Building Indigenous community governance in Australia: Preliminary research findings. Canberra, NZ: Centre for Aboriginal Economic Policy Research Working Paper 31.

Keller, B., \& Mbewe, D.C. (1991). Policy and planning for the empowerment of Zambia's women farmers. Canadian Journal of Development Studies, 12(1), 75-88.

Kretzmann, J.P., \& McKnight, J.L. (1993). Building communities from the inside out: A path toward finding and mobilizing a community's assets. Evanston, IL: Institute for Policy Research.

Li, W.J. (2006). Community decision-making participation in development. Annals of Tourism Research, 33(1), 132-143.

Liu, A. (2006). Tourism in rural areas: Kedah, Malaysia. Tourism Management, 27(5), 878-889.

McGinley, R. (2002). Best practices: A planned approach to developing a sustainable aboriginal tourism industry in Mistissini. Journal of Aboriginal Economic Development, 3(2), 12-19.

Mitchell, R., \& Eagles, P. (2001). An integrative approach to tourism: Lessons from the Andes of Peru. Journal of Sustainable Tourism, 9(1), 4-28.

Mvula, C. (2001). Fair trade in tourism to protected areas: A micro case study of wildlife tourism to south Luangwa national park, Zambia. Canterbury Christ Church University College, Centre for Tourism and Leisure, Department of Geography and Tourism, Canterbury, UK.

Nepal, S. (2007). Local level institutions in tourism management in Nepal's Annapurna Region. In R. Butler \& T. Hinch (Eds.), Tourism and indigenous peoples (pp. 234-250). Burlington, MA: Elsevier.

Notzke, C. (2004). Indigenous tourism development in southern Alberta, Canada: Tentative engagement. Journal of Sustainable Tourism, 12(1), 29-54. 
Nyamweru, C., \& Kimaru, E. (2008). The contribution of ecotourism in the conservation of natural sacred sites: A case study from coastal Kenya. Journal for the Study of Religion, Nature and Culture, 2(3), 327-350.

Parker, B. (1993). Developing aboriginal tourism: Opportunities and threats. Tourism Management, $14,400-404$.

Reid, D.G., \& van Dreunen, E. (1996). Leisure as a social transformation mechanism in community development practice. Journal of Applied Recreation Research, 27(1), 45-65.

Royal Commission on Aboriginal Peoples. (1996). Report of the Royal Commission on Aboriginal Peoples. Indian and Northern Affairs Canada. Ottawa, ON: Ministry of Supply and Services Canada.

Salole, M. (2007). Merging two disparate worlds in rural Namibia: Joint venture tourism in Torra conservancy. In R. Butler \& T. Hinch (Eds.), Tourism and indigenous peoples (pp. 205-219). Burlington, MA: Elsevier Ltd.

Sandmeyer, A.E. (2005). Community-based ecotourism and sustainable community development: Exploring the relationship. Unpublished master's thesis, Dalhousie University, Halifax, NS.

Scheyvens, R. (1999). Ecotourism and the empowerment of local communities. Tourism Management, 20, 245-249.

Scheyvens, R. (2002). Tourism for development: Empowering communities. Harlow, UK: Prentice Hall.

Simpson, L. (2005). Community informatics and sustainability: Why social capital matters. The Journal of Community Informatics, 1(2), 1-21.

Simpson, L., Wood, L., \& Daws, L. (2003). Community capacity building: Starting with people not projects. Community Development Journal, 38, 277-286.

Smith, V.L. (1996). Indigenous tourism: The four h's. In R. Butler \& T. Hinch (Eds.), Tourism and indigenous peoples (pp. 283-307). London: International Thomson Business Press.

Sofield, T. (2002). Australian aboriginal ecotourism in the Wet Tropics Rainforest of Queensland, Australia. Mountain Research and Development, 22(2), 118-122.

Sofield, T., \& Birtles, R. (1996). Indigenous peoples' cultural opportunity spectrum for tourism (IPCOST). In R. Butler \& T. Hinch (Eds.), Tourism and indigenous peoples (pp. 396-433). London: International Thomson Business Press.

Stone, W., \& Hughes. J. (2002). Social capital: Empirical meaning and measurement validity. Research Paper 27, Australian Institute of Family Studies, Melbourne, Australia. Retrieved September 2009 from: http://www.aifs.gov.au/institute/pubs/stone2.html

Telfer, D.J. (2002). The evolution of tourism and development theory. In R. Sharpley \& D.J. Telfer (Eds.), Tourism and development: Concepts and issues (pp. 35-80). Clevedon, UK: Channel View Publications.

Vodden, K. (2002). Sustainable community economic development in a coastal content: The case of Alert Bay, British Columbia. Journal of Aboriginal Economic Development, 3(1), 45-58.

Wang, Y., \& Wall, G. (2005). Sharing the benefits of tourism: A case study in Hainan, China. Environments Journal, 33(1), 41-59.

Warry, W. (2000). Unfinished dreams: Community healing and the reality of aboriginal selfgovernment. Toronto, ON: University of Toronto Press.

Weaver, D. (2009). Indigenous tourism stages and their implications for sustainability. Journal of Sustainable Tourism, 17(6), 1-18.

Wi'la'mola Project. (2009). We are all in this together. Journal of Aboriginal Economic Development. Retrieved from http://www.edo.ca/edo-tools/journals

Zeppel, H. (1998). Land and culture: sustainable tourism and indigenous peoples. In C.M. Hall \& A.A. Lew (Eds.), Sustainable tourism: a geographical perspective (pp. 60-74). Essex: Longman.

Zeppel, H. (2006). Indigenous tourism: Sustainable development and management. Wallingford, UK: CABI. 